\title{
Peningkatan Keterampilan Sosial Melalui Penerapan Model Time Token Pada Subtema Keunikan Daerah Tempat Tinggalku Kelas IV MI Al-Azhar Menganti Gresik
}

\author{
Nurul Agustin \\ STAI Al-Azhar Menganti Gresik \\ email: nurulagustinstaialazhar@gmail.com
}

\begin{abstract}
Learning on the sub-theme of the uniqueness of the area where I live in MI Al-Azhar Menganti Gresik there are still students who like to tease friends who are not right in answering questions from the teacher, there are still students who like to say harshly or underestimate friends if there are borrowing stationery, there are still students who do not want to cooperate with other students, and the lack of interaction between teachers and students, students and other students because teachers are still teacher centered because they are still dominated by teachers and do not involve students in teaching and learning. Teachers also use less and learning models so that students feel bored and tend to ignore material explanations from the teacher. So it does not only affect student learning outcomes that are low as well as affect students 'social skills. Therefore, the researcher updates the presentation of learning through the application of the Time Token model to improve students' social skills. The objectives to be achieved are to describe students 'activities and describe the improvement of students' social skills in applying the Time Token model. The results of data analysis showed that the activity of students in the first cycle reached $68.5 \%$ and in the second cycle increased to $85.5 \%$. Likewise the social skills of students in the first cycle reached $78 \%$ in the Good category and in the second cycle increased to $87 \%$ in the Very Good category. Based on these results it can be concluded that the learning on the sub-theme of the Uniqueness of the Area Where I Live through the application of the Time Token model can increase with very good categories. Based on these results, it can be concluded that through the application of the Time Token model students' social skills can be improved.
\end{abstract}

Keywords: Social Skills, Time Token Model

\begin{abstract}
Abstrak
Pembelajaran pada subtema Keunikan Daerah Tempat Tinggalku di MI Al-Azhar Menganti Gresik masih ada siswa yang suka mengejek teman yang kurang tepat dalam menjawab pertanyaan dari guru, masih ada siswa yang suka berkata kasar atau meremehkan teman jika ada yang meminjam peralatan tulis, masih ada siswa yang tidak mau bekerja sama dengan siswa lainnya, dan kurangnya interaksi antar guru dan siswa, siswa dengan siswa yang lain dikarenakan guru masih berbasis teacher centered karena masih didominasi oleh guru dan kurang melibatkan siswa dalam proses belajar mengajar. Guru juga kurang menggunakan dan model pembelajaran sehingga siswa merasa bosan dan cenderung mengabaikan penjelasan materi dari guru. Sehingga bukan hanya
\end{abstract}


mempengaruhi hasil belajar siswa yang rendah serta mempengaruhi keterampilan sosial siswa.Oleh karena itu, peneliti melakukan pembaruan penyajian pembelajaran melalui penerapan model Time Token untuk meningkatkan keterampilan sosial siswa. Tujuan yang hendak dicapai mendiskripsikan aktivitas siswa dan mendiskripsikan peningkatan keterampilan sosial siswa dalam penerapan model Time Token. Hasil analisis data menunjukkan bahwa pada aktivitas siswa pada siklus I mencapai $68,5 \%$ dan pada siklus II meningkat menjadi $85,5 \%$. Begitu juga pada keterampilan sosial siswa pada siklus I mencapai $78 \%$ dengan kategori Baik dan pada siklus II meningkat menjadi $87 \%$ dengan kategori sangat Baik. Berdasarkan hasil tersebut dapat disimpulkan pembelajaran pada subtema Keunikan Daerah Tempat Tinggalku melalui penerapan model Time Token dapat meningkat dengan kategori sangat baik. Berdasarkan hasil tersebut, dapat disimpulkan bahwa melalui penerapan model Time Token keterampilan sosial siswa dapat ditingkatkan.

\section{Kata Kunci : Keterampilan Sosial, Model Time Token}

\section{PENDAHULUAN}

Pendidikan

pembelajaran,

keterampilan, dan kebiasaan

sekelompok orang yang diturunkan

dari satu generasi ke generasi

berikutnya dengan melalui

pengajaran, pelatihan, atau penelitian.

Dari pengertian di atas dapat dikatakan bahwa pendidikan sangat dibutuhkan dalam menunjang pengetahuan atau pelatihan serta usaha sadar dengan cara yang sistematis dan dinamis yang bertujuan meningkatkan potensi peserta didik.

Sugiono (dalam Rahmadani, 2019:56) dalam UUSP No.20 tahun 2003 pasal 1 ayat 1 dikemukakan bahwa "Pendidikan adalah usaha sadar terencana untuk mewujudkan suasana belajar dan proses pembelajaran agar peserta didik secara aktif mengembangkan potensi dirinya untuk memilikki kekuatan spiritual keagamaan, pengendalian diri, kepribadian, kecerdasan, akhlak muli, serta keterampilan yang diperlukan dirinya, masyarakat, bangsa, dan Negara”.

Suatu pendidikan dikatakan berkualitas, apabila pada proses pembelajaran dapat berlangsung secara efektif dan siswa mengalami proses pembelajaran yang bermakn serta dalam kegiatan pembelajaran saling berhubungan, belajar dan mengajar harus saling mempengaruhi. Dalam implementasi proses pendidikan ada beberapa komponen yang menunjang keberhasilan siswa yaitu: guru sebagai sumber dan alat belajar siswa, tujuan pembelajaran, strategi, metode dan model belajar mengajar.

Keberhasilan suatu pendidikan tidak hanya diukur dari pencapaian kognitif, dari segi afektif dan perilaku juga sangat penting, dengan adanya sikap saling menghargai dan menghormati baik di dalam sekolah maupun di luar sekolah juga perlu diperhatikan.

Menurut Riggio

keterampilan sosial adalah

kemampuan komunikasi verbal dan 
non verbal termasuk ekpresivitas, sensitivitas, dan kontrol. Ekpresivitas mengacu pada keterampilan berkomunikasi atau mengirim pesan kepada orang lain.sensitivitas mengacu pada keterampilan menerima dan menafsirkan pesan yang dikomunikasikan orang lain. Kontrol mengacu pada keterampilan yang mampu mengatur dan mengelola kemampuan proses komunikasi.

Yamin (2010:4) mengatakan bahwa "keterampilan sosial adalah kemampuan berempati, memahami sudut pandang teman dan menghargai adanya perbedaan pendapat antar sesama.

\section{Nandang}

(2006:21)

menyatakan bahwa keterampilan sosial yang dipandang penting bagi anak adalah keterampilan berkomunikasi , keterampilan menyesuaikan diri, dan keterampilan menjalin hubungan baik dengan lingkungannya.

Dari hasil observasi di kelas IV MI Al-Azhar Menganti Gresik, peneliti mengetahui bahwa pembelajaran berlangsung di kelas IV masih ada siswa yang suka mengejek teman yang kurang tepat dalam menjawab pertanyaan dari guru, masih ada siswa yang suka berkata kasar atau meremehkan teman jika ada yang meminjam peralatan tulis, masih ada siswa yang tidak mau bekerja sama dengan siswa lainnya, dan kurangnya interaksi antar guru dan siswa, siswa dengan siswa yang lain.

Pembelajaran dikelas cenderung terpusat pada guru (teacher centered) dengan menggunakan metode ceramah dan tugas. Disini guru kurang kreatif dalam mengelola kelas pada saat proses pembelajaran berlangsung. Guru kurang menggunakan media pembelajaran, tidak menggunakan metode atau model pembelajaran aktif terhadap siswa. Siswa cenderung bosan dan sesekali mengantuk dalam pembelajaran berlangsung, karena siswa tidak dilibatkan secara langsung pada saat proses pembelajaran. Guru pun kurang mengaitkan materi pembelajaran dengan pengalaman dan kehidupan siswa sehingga siswa kurang mendapatkan pembelajaran yang bermakna. Siswa tidak diberi kesempatan untuk mengungkapkan pendapat dan kurang adanya kerjasama antar kelompok. Dengan adanya permasalahan tersebut menyebabkan keterampilan sosial siswa kurang berkembang.

Pada pembelajaran subtema Keunikan Daerah Tempat Tinggalku yang mempelajari tentang beragam keunikan masing-masing daerah, keunikan fisik seperti sungai, gunung, sawah dan bentuk rumah serta keunikan sosial budaya seperti adat istiadat, seni dan Bahasa. Dengan melalui pembelajaran subtema tersebut, masing-masing siswa pasti mempunyai cerita atau pengalaman tersendiri karena masing-masing siswa mempunyai kota asal atau daerah asal dengan keunikan tersendiri.

Dengan adanya penggunaan model Time Token, siswa menjadi lebih aktif dalam kegiatan 
pembelajaran, mendorong siswa untuk meningkatkan inisiatif dan partisipasinya, melatih siswa untuk mengungkapkan pendapatnya serta meningkatkan kemampuan siswa dalam berkomunikasi (aspek berbicara).

Menurut Taniredja, dkk (2014:119) “ Model pembelajaran Time Token merupakan struktur yang dapat digunakan untuk mengajarkan keterampilan sosial, untuk menghindari siswa mendominasi pembicaraan atau siswa diam sama sekali”.

Peneliti terdorong untuk mengungkapkan peningkatan keterampilan sosial melalui model Time Token pada siswa kelas IV MI Al-Azhar Menganti Gresik. Dengan meningkatkan keterampilan sosial anak melalui pendidikan anak tersebut akan mampu melakukan kegiatan-kegiatan sebagai makhluk sosial untuk memenuhi kebutuhan masyarakat.

\section{METODE PENELITIAN}

Penelitian ini merupakan penelitian tindakan kelas (PTK) yang berfokus pada peningkatan keterampilan sosial siswa melalui penerapan model Time Token pada subtema Keunikan Daerah Tempat Tinggalku MI kelas IV.

Penelitian ini dilaksanakan dengan menggunakan metode deskriptif kualitatif. Prosedur pelaksanaannya mengikuti prinsip dasar penelitian tindakan kelas. Penelitian tindakan diawali dengan mengidentifikasi gagasan umum yang dispesifikasikan sesuai dengan tema penelitian, spesifikasi gagasan tersebut lebih lanjut dilaksanakan melalui empat tahapan secara berdaur ulang yaitu perencanaan, pelaksanaan, tindakan, pengamatan, dan refleksi (perenungan, pemikiran, evaluasi).

Dalam PTK ini yang menjadi subjek penelitian adalah siswa kelas IV MI Al-Azhar Menganti Gresik pada subtema Keunikan Daerah Tempat Tinggalku yang terdiri dari 30 siswa dengan komposisi 17 siswa perempuan dan 13 siswa laki-laki.

Penelitian ini dirancang melalui tahap siklus PTK. Setiap siklus ada empat tahapan, yaitu (1) perencanaan; (2) pelaksanaan tindakan; (3) pelaksanaan pengamatan dan (4) refleksi.

Teknik pengumpulan data dengan menggunakan, (1)observasi; dan (2) angket;

Obervasi untuk mengamati kegiatan belajar mengajar berlangsung, aktivitas yang dilakukan guru dan siswa. Angket untuk mengetahui respond dan pandangan siswa tentang pembelajaran dengan menggunakan model Time Token. Teknik analisis data dari data kualitatif dan kuantitatif. Analisis data dalam penelitian kualitatif dilakukan sejak sebelum dan selama penelitian berlangsung, pada penelitian ini diperoleh dari hasil observasi yang dilakukan pada kegiatan guru dalam menggunakan model Time Token dan kegiatan siswa dalam pembelajaran dengan menggunakan model Time Token. Observer (penelitian dan teman 
sejawat) yang hasilnya dijadikan sebagai bahan diskusi antara guru dan observer yang digunakan untuk menentukan langkah - langkah kegiatan belajar mengajar pada siklus berikutnya. Analisis data kuantitatif diperoleh dari hasil tes yang bertujuan untuk mengetahui hasil belajar siswa, hasil analisis aktivitas guru dan aktivitas siswa pada keterampilan sosial anak. Data yang diperoleh dengan angket menggunakan analisis secara kuantitatif.

\section{HASIL DAN PEMBAHASAN Deskripsi Siklus I}

Siklus I dilaksanakan pada tanggal 15 April 2019 kegiatan proses pembelajaran yang diawali pada tahap pelaksanaan berupa penerapan model Time Token dengan subtema Keunikan Daerah Tempat Tinggalku yang telah dirancang dalam RPP. Adapun kegiatan pembelajaran terdiri dari beberapa tahap. Pada tahap pendahuluan, ada beberapa aktivitas guru dan siswa. Aktivitas guru yaitu; (1) guru menyampaikan tujuan pembelajaran; (2)guru meminta siswa mengamati materi yang telah diberikan; (3)guru menjelaskan tentang materi pada subtema "Keunikan Daerah Tempat Tinggalku"; (4)guru membagi siswa ke dalam 5 kelompok; (5)guru menyampaikan kupon berbicara dengan waktu 30 detik; (6)guru menjelaskan langkah-langkah pembelajaran model Time Token; (7)guru tanya jawab dengan siswa tentang model Time Token; (8) guru membawa gambar rumah adat, cendera mata khas daerah dan melakukan tanya jawab dengan siswa tentang gambar tersebut; (9)guru meminta siswa untuk berdiskusi; (10)guru meminta siswa untuk memberikan pendapat tentang gambar tersebut menggunakan kupon tersebut; (11)guru meminta setiap kelompok untuk berdiskusi dan menyimpulkan hasil pendapat dari setiap siswa; (12)guru membagikan LKPD pada setiap masing-masing kelompo; (13)guru mengarahkan siswa untuk mengerjakan LKPD secara bersama-sama; (14) guru meminta siswa dari setiap kelompok maju kedepan untuk mempresentasikan hasil kerja kelompoknya; (15)guru meminta siswa untuk presentasi; (16) guru memberikan evaluasi pada kegiatan pembelajaran; (17) guru memberikan soal post test pada masing-masing siswa; (18)guru meminta siswa memberikan kesimpulan; (19)guru memberikan kesempatan kepada siswa untuk meyampaikan pendapat/menyimpulkan tentang materi; (20)guru mengajak siswa mengakhiri pembelajaran dengan berdo'a bersama-sama .

Adapun aktivitas siswa dengan indikator keterampilan sosial siswa yaitu : (1)penuh pengertian dengan sesama teman, (2)siswa berpartisipasi secara tepat dalam pembicaraan kecil, (3)kepedulian sesama teman, (4)siswa menanggapi pendapat dengan humor, (5)tenggang rasa atau menghormati pendapat orang lain, (6)siswa membantu kelompok lain yang kesulitan dalam 
menjawab pertanyaan atau dalam mengerjakan tugas, (7)kesopanan, (8)siswa mematuhi perintah guru, (9)siswa menjadi pendengar yang responsif, dan (10)kemandirian.

Peneliti dibantu oleh teman sejawat sebagai observer untuk melakukan pengamatan aktivitas siswa selama kegiatan pembelajaran berlangsung dengan menggunakan model Time Token. Berdasarkan data hasil observasi kegiatan siswa dengan menggunakan model Time Token pada siklus I, berdasarkan data, sebanyak 13 siswa atau $43 \%$ siswa dengan kategori tingkat keterampilan sosial baik, sebanyak 10 siswa atau $33 \%$ dengan kategori tingkat keterampilan sosial baik dan sebanyak 7 siswa atau $24 \%$ dengan tingkatan kategori keterampilan sosial cukup. Hasil presentasi klasikal tingkat keterampilan sosial siswa mencapai $78 \%$ dengan kategori baik. Refleksi, berdasarkan hasil pengamatan, peneliti dibantu teman sejawat atau observer melakukan refleksi sebagai evaluasi terhadap kegiatan pembelajaran yang telah dilakukan pada siklus I. Data diatas akan dijadikan acuan dalam siklus II.

\section{Dekripsi Siklus II}

Siklus II dilaksanakan pada tanggal 22 April 2019 kegiatan proses pembelajaran yang diawali pada tahap pelaksanaan berupa penerapan model Time Token dengan subtema Keunikan Daerah Tempat Tinggalku yang telah dirancang dalam RPP. Adapun kegiatan pembelajaran terdiri dari beberapa tahap. Pada tahap pendahuluan, ada beberapa aktivitas guru dan siswa. Aktivitas guru yaitu; (1) guru menyampaikan tujuan pembelajaran; (2)guru meminta siswa mengamati materi yang telah diberikan; (3)guru menjelaskan tentang materi pada subtema "Keunikan Daerah Tempat Tinggalku"; (4)guru membagi siswa ke dalam 5 kelompok; (5)guru menyampaikan kupon berbicara dengan waktu 30 detik; (6)guru menjelaskan langkah-langkah pembelajaran model Time Token; (7)guru tanya jawab dengan siswa tentang model Time Token; (8) guru membawa gambar rumah adat, cendera mata khas daerah dan melakukan tanya jawab dengan siswa tentang gambar tersebut; (8)guru meminta siswa untuk berdiskusi; (9)guru meminta siswa untuk memberikan pendapatna tentang gambar tersebut menggunakan kupon tersebut; (10)guru meminta setiap kelompok untuk berdiskusi dan menyimpulkan hasil pendapat dari setiap siswa; (11)guru membagikan LKPD pada setiap masing-masing kelompok; (12)guru mengarahkan siswa untuk mengerjakan LKPD secara bersama-sama; (13) guru meminta siswa dari setiap kelompok maju kedepan untuk mempresentasikan hasil kerja kelompoknya; (14)guru meminta siswa untuk presentasi; (15) guru memberikan evaluasi pada kegiatan pembelajaran; (16) guru memberikan soal post test pada masing-masing siswa; (17)guru meminta siswa memberikan kesimpulan; (18)guru 
memberikan kesempatan kepada siswa untuk meyampaikan pendapat/menyimpulkan tentang materi; (20)guru mengajak siswa mengakhiri pembelajaran dengan berdo'a bersama-sama .

Adapun aktivitas siswa dengan indikator keterampilan sosial yaitu : (1)menggunakan kontak mata dengan orang lain ketika berbicara, (2)siswa berpartisipasi secara tepat dalam pembicaraan kecil, (3)siswa mampu menampung komentar dan ide-ide orang lain, (4)siswa menanggapi dengan humor, (5)siswa mencermati pemahaman orang dan mengajukan pertanyaan yang sesuai, (6)siswa menjalankan arahan dari guru, (7)siswa menyelesaikan tugas dengan baik, (8)siswa mematuhi perintah guru, (9)siswa menjadi pendengar yang responsif, dan (10)tegas dalam mengajukan pertanyaan.

Peneliti dibantu oleh teman sejawat sebagai observer untuk melakukan pengamatan aktivitas siswa selama kegiatan pembelajaran berlangsung dengan menggunakan model Time Token.

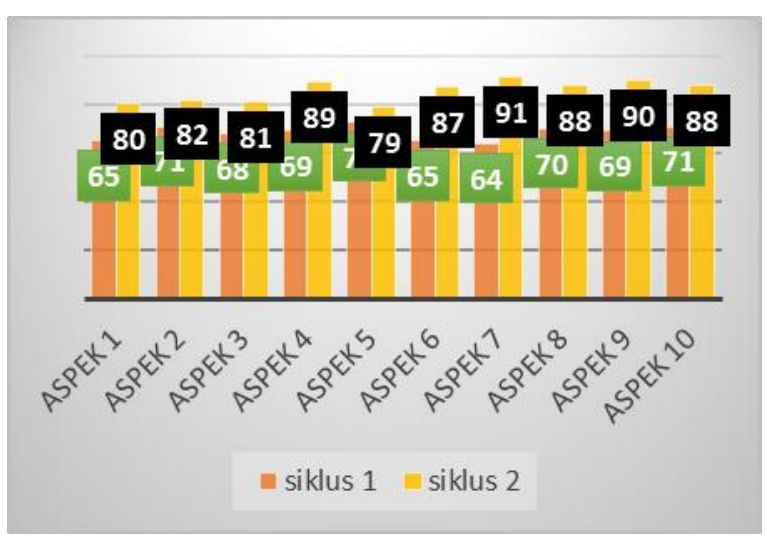

Gambar 4.1. Diagram Perbandingan Hasil Observasi Siswa

Berdasarkan data hasil observasi kegiatan siswa dengan menggunakan model Time Token pada siklus II berdasarkan data, sebanyak 27 siswa atau $90 \%$ siswa dengan kategori tingkat keterampilan sosial sangat baik, sebanyak 3 siswa atau $10 \%$ dengan tingkat keterampilan sosial baik dengan kategori tingkatan keterampilan sosial baik. Hasil presentasi klasikal tingkat keterampilan sosial siswa mencapai $87 \%$ dengan kategori sangat baik. Dari hasil refleksi dapat disimpulkan bahwa pada siklus II sudah memenui indikator keberhasilan yaitu $\geq 80 \%$. Berdasarkan hasil data diatas penelitian ini dinyatakan sudah cukup dilaksanakan sampai siklus II.

Tabel. 4.2 Perbandingan Penilaian Keterampilan Sosial siswa Siklus I dan II

\begin{tabular}{|l|c|c|c|c|}
\hline & \multicolumn{3}{|c|}{ Kategori } & \multirow{2}{*}{$\%$} \\
\cline { 2 - 5 } & Cukup & Baik & $\begin{array}{c}\text { Sangat } \\
\text { Baik }\end{array}$ & \\
\hline Siklus 1 & $24 \%$ & $33 \%$ & $43 \%$ & $78 \%$ \\
\hline Siklus 2 & - & $10 \%$ & $90 \%$ & $87 \%$ \\
\hline
\end{tabular}

Berdasarkan data hasil observasi aktivitas siswa dalam setiap aspek mengalami peningkatan. Aspek 1 pada siklus I mencapai $65 \%$ dan pada siklus II meningkat menjadi $80 \%$. Aspek 2 pada siklus I mencapai $71 \%$ dan pada siklus II meningkat menjadi $82 \%$. Aspek 3 pada siklus I mencapai $68 \%$ dan pada siklus II meningkat menjadi $81 \%$. Aspek 4 pada siklus I mencapai $69 \%$ dan pada siklus II meningkat menjadi 89\%. Aspek 5 pada siklus I mencapai $73 \%$ dan pada 
siklus II meningkat menjadi $79 \%$. Aspek 6 pada siklus I mencapai $65 \%$ dan pada siklus II meningkat menjadi 87\%. Aspek 7 pada siklus I menacapai $64 \%$ dan pada siklus II meningkat menjadi 91\%. Aspek 8 pada siklus I mencapai $70 \%$ dan pada siklus II meningkat menjadi $88 \%$. Aspek 9 pada siklus I mencapai 69\% dan pada siklus II meningkat menjadi 90\%. Aspek 10 pada siklus I mencapai $71 \%$ dan pada siklus II meningkat menjadi $88 \%$.Data diatas menunjukkan adanya peningkatan pada aktivitas siswa dalam pembelajaran subtema Keunikan Daerah Tempat Tinggalku dengan penerapan model Time Token.

\section{SIMPULAN}

Keterampilan sosial siswa meningkat dilakukan pembelajaran dengan subtema Keunikan Daerah Tempat Tinggalku melalui penerapan model Time Token. Rata - rata tingkatan keterampilan sosial anak pada siklus I mencapai $78 \%$ dengan kategori Baik dan pada siklus II meningkat menjadi $87 \%$ dengan kategori sangat Baik.

Berdasarkan hasil penelitian saran yang dapat diberikan kepada guru sebagai berikut. Guru harus lebih kreatif dalam menyampaikan materi pada siswa saat proses pembelajaran berlangsung. Dengan menggunakan model Time Token dapat meningkatkan keterampilan sosial anak di MI.

\section{DAFTAR RUJUKAN}

Arends, R. I. (1998). Learning To Teach. Singapore:Mc GrawHill Book Company

Nandang, Budiman. 2006. Memahami Perkembangan Anak Usia Sekolah Dasar. Jakarta: Depdiknas

Rahmadani, Aprianti. 2019. Kefektifan Model Pembelajaran Kooperatif Tipe TGT (Team Games Tournament) Pada Pokok Bahasan Pecahan Sederhana Kelas III SDN Tanjungsari 1 Sidoarjo. Trapsila: Jurnal Pendidikan Dasar, 1 (1), 5571.

Riggio, Ronald.E. 1986. Assesment of Basic Social Skills. Jounal of Personality and Social Pschology. Vol 51, no.3.

Setiana, Tita. (2014). Peningkatan Keterampilan Sosial Siswa Melalui Penerapan Metode Simulasi Pada Pembelajaran IPS Kelas V SD Negeri Pakem 2 Sleman

Suharsimi Arikunto. (2002). Penelitian Kelas Untuk Guru, Kepala Sekolah \& Pengawas. Yogjakarta: Aditya Media

Taniredja, Tukiran. 2014. ModelModel Pembelajaran Inovatif dan Efektif. Bandung: Alfabeta

Yamin, Martinis. 2010. Kiat Membelajarkan Siswa, Jakarta: Gaung Persada Press 